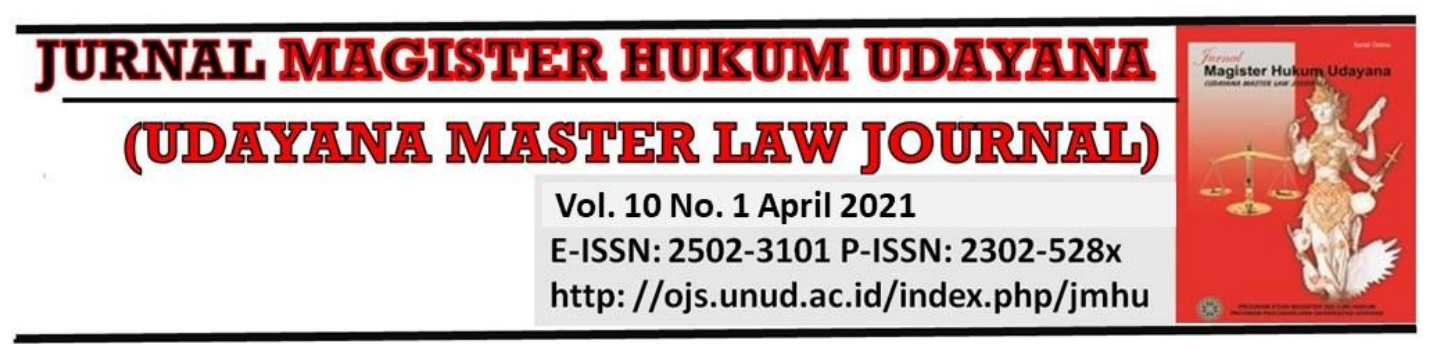

\title{
The Penal Policy Formulation in Cyberporn Crime Countermeasures
}

\author{
I Made Wirya Darma1 \\ ${ }^{1}$ Faculty of Law and Social Sciences, Universitas Pendidikan Nasional, \\ E-mail: dedukdd81@gmail.com
}

\begin{tabular}{|c|c|}
\hline Info Artikel & Abstract \\
\hline $\begin{array}{l}\text { Received: } 18^{\text {th }} \text { April } 2020 \\
\text { Accepted: } 4^{\text {th }} \text { April } 2021 \\
\text { Published: } 9^{\text {th }} \text { April } 2021 \\
\text { Keywords: } \\
\text { Countermeasures; Cyberporn } \\
\text { Penal Policy } \\
\text { Corresponding Author: } \\
\text { I Made Wirya Darma, } \\
\text { E-mail: dedukdd81@gmail.com } \\
\text { DOI: } \\
\text { 10.24843/JMHU.2021.v10.i01. } \\
\text { p03 }\end{array}$ & $\begin{array}{l}\text { Criminal law reform must be based on correctional policies. } \\
\text { Criminal policy can be defined as selective behavior to achieve the } \\
\text { best criminal law that will serve justice and usefulness. This } \\
\text { paper examines criminal policies in the eradication of cyberporn } \\
\text { related to technological advances and the development of society } \\
\text { in the use of internet technology in all sectors, including } \\
\text { education, workplaces, companies, and so on. This research uses } \\
\text { normative legal research methods. The approach used is the } \\
\text { statutory approach and conceptual approach. The results of the } \\
\text { study show that with the existence of a criminal system as a form } \\
\text { of criminal action settlement, the existence of statutory } \\
\text { regulations is expected to improve the repressive function of } \\
\text { criminal law. One of the efforts to eradicate cyberporn through } \\
\text { the criminal system is to formulate regulations, including: } \\
\text { KUHP, Law no. } 40 \text { of } 1999 \text { concerning the Press, Law no. } 32 \text { of } \\
2002 \text { concerning Broadcasting, Law no. } 19 \text { of } 2016 \text { concerning } \\
\text { Information and Electronic Transactions, Law Number } 33 \text { of } \\
2009 \text { concerning Films. However, these laws are still lacking to } \\
\text { keep up with the rapid increase in cyberporn, due to the lack of } \\
\text { unclear pornography regulations. Therefore, reform of criminal } \\
\text { law in Indonesia is urgently needed, especially with the fact that } \\
\text { the Criminal Code is currently a product of colonial law. }\end{array}$ \\
\hline
\end{tabular}

\section{Introduction}

The development of technology is needed to support human life. In one hand, technology is very useful for the progress of Indonesian people, but on the other hand, there are also many technology abuses. Related to this, Puspasari states "The technological advances in addition to a positive impact, in the sense that can be utilized for the benefits of mankind also bring negative impacts on human development and civilization. The negative impact in question is related to the world of crime." 1 The virtual space becomes a place used by perpetrators to commit crimes. For example, sending harassment messages online can be categorized as a computer-assisted crime, a crime that falls into a larger umbrella term, cybercrime. ${ }^{2}$

\footnotetext{
${ }^{1}$ Ratih Mega Puspasari, "Reconstruction of Criminal Sanctions On Actors Of Online Prostitution Based On Justice Value," Law Development Journal 1, no. 1 (2019): 32-38.

2 Adam M Bossler and Tamar Berenblum, "Introduction: New Directions in Cybercrime Research" (Taylor \& Francis, 2019).
} 
One of the crimes that is committed online is cyberporn. Cyber Porn can be defined as an act of creating, displaying, distributing, publishing pornography and obscene material by using cyberspace. ${ }^{3}$ Countries have implemented mechanism to block pornography. ${ }^{4}$ Criminal law in the eradication of cyberporn is always associated with the advancement of technology that can not be separated from the development of the society that utilizes internet technology in various fields both in the fields of education, offices, and companies and so on. That is what allows more opportunities to access the internet. Many of the problems that arise as a result of this, especially in Indonesia, where such things are not allowed in a civilized and Pancasila nation. There are many negative implications for beginners who are unaware of the usefulness of the internet. Especially for teenagers who often try to open sites that are not allowed. Even worse if the children are still innocent and they are exposed by sites that are less suitable for their development. It is very dangerous for the mental development of children and teenagers.

There are two elements that play critical roles in rule breaking behaviors, first, morality and second, low self-control. ${ }^{5}$ For this reason, policies are needed to combat cyberporn to minimize crime in cyberspace in the field of decency which is currently rife. From the perspective of criminal police, crime countermeasures efforts (including cyberporn countermeasures) certainly cannot be conducted partially with criminal law (penal means), but must be a comprehensive approach. This form of crime in cyberspace is one form of high tech crime, it is natural that efforts to tackle cyberporn must also be pursued with a technological approach (techno prevention).

The crime prevention approach in modern criminal law does not only rely on the side of the penal policy, but non-penal policy needs to be implemented to prevent cyber porn. Cultural or cultural approaches, moral or educational approaches (especially for moral offenses), and even global approaches (international cooperation) because cyberporn can cross national borders (transnational or transborder). This approach needs to be implemented bearing in mind that crimes committed in cyberspace have a greater tendency to expand.

The lack of criminal law coverage shows that the inclusion of non-penal means of cyberporn resolution is needed, which is through techno prevention, cultural approach, moral/educative approach, global/international cooperation approach, as well as scientific approach. These efforts require awareness, cooperation, and participation from all sides, including the government, internet service providers, educational institution, the society, parents, users, as well as regional and international cooperations. Such integration shall be carried out as a means of harmonizing the substance of crimes as well as harmonizing the policy making on cyberporn crime, whether in an international, regional, or national level. Meanwhile, the subject of crime includes person and/or corporation, the formulation of crime are explicit/specific to

\footnotetext{
${ }^{3}$ Hervina Puspitosari and Ashinta Sekar Bidari, "ETHIC CYBER STRENGTHENING ASCRIMINAL LAW POLICY FORMULATIONS IN RESPONSE CYBERPORN," UNTAG Law Review 1, no. 2 (2017): 30-37.

4 J L Jamaldi and Ferdi Ferdi, "TEKNIK DAN TAKTIK PENYIDIK DALAM PENETAPAN TERSANGKA PADA TINDAK PIDANA PORNOGRAFI MELALUI INTERNET (Studi Pada Direktorat Reserse Kriminal Khusus Polda Sumbar)," UNES Law Review 1, no. 3 (2019): 282-90.

5 Jaeyong Choi and Ilhong Yun, "Do Moral Beliefs Condition the Impact of Low Self-Control on Digital Piracy?," Deviant Behavior, 2019, 1-13.
} 
include all forms of conducts and all forms of pornography in the internet, as well as the concrete formulation of pornography act as a part of the element of crime.

Through crime countermeasures policies using penal means, the existence of a law is obviously expected to further enhance the repressive function of criminal law. One of the efforts to tackle cyberporn crimes through the penal means is to apply the provisions of applicable laws such as the Criminal Code, Law Number 40 of 1999 concerning the Press, Law Number 32 of 2002 concerning Broadcasting, Law Number 19 of 2016 concerning Information and Electronic Transactions, Law Number 33 of 2009 concerning Film. However, apparently, the law still has limitations to compensate for the increasingly rapid development of cyberporn, including the provision of unclear pornographic restrictions. In resolving a modern and technology based crime, there needs to be a modern policy formulation as well, which shall include the maximum synergy in enforcing the applicable legislation as well as in reforming the criminal law in Indonesia. These can be done through the RUU KUHP (Criminal Code Bill) which was drafter accordingly with the needs of the society and the current development in crimes.

Based on this, it can be seen that the efforts to deal with cyberporn crime through penal means still have limitations, which are always left behind from all forms of new crimes that develop along with advances in information and technology. Thus, in the handling of cyberporn, it cannot only be done by using the penal means alone, but it must also be supported by non-penal means which are more preventive. Therefore, in this research, there will be an analysis of the issue on penal policy formulation with regards to the resolution of cyberporn in the criminal law frameworks of Indonesia.

Hopefully this writing could contribute and play a role in the development of knowledge on the related matters. Some earlier research which has analyzed the formulation of penal policy in resolving the crime of cyberporn had been found in legal writings whether journal article or thesis, including the research conducted by Rosalind A Fanggi ${ }^{6}$ in Yurisprudensia Law Journal, which analyzed the Peanl Policy as a Means of Resolving Cyberporn, as well as the thesis written by Dwi Haryadi, S.H.7, a master student in the Law Faculty of Universitas Diponegoro by the year of 2007, who has analyzed the Penal Policy Formulation on the Resolution of Cyberporn as a Part of Criminal Law Reformation in Indonesia.

\section{Research Method}

The research method used in this research is normative juridical research methods. The preparation of this research is analytical descriptive, by describing data or a picture as carefully as possible about the object of the problem. The technique of collecting legal materials in accordance with the above research stage is by conducting a literature study consisting of researching of documents of national legal instruments, laws and regulations that directly related with the eradication of cyberporn crimes namely the provisions of the Criminal Law Code especially in Draft Book of Criminal Law 2019,

\footnotetext{
${ }^{6}$ Rosalind and A Fanggi, "Kebijakan Hukum Pidana Dalam Upaya Penanggulangan Cyberporn,” Jurnal Hukum Yurisprudeensia 17, no. 7 (2019).

${ }^{7}$ Dwi and Haryadi, "Kebijakan Formulasi Hukum Pidana Terhadap Penanggulangan Cyberporn Dalam Rangka Pembaharuan Hukum Pidana Di Indonesia," in Pembaharuan Hukum Pidana Di Indonesia, Program Magister Ilmu Hukum Universitas Diponegoro, 2007.
} 
Law Number 40 of 1999 concerning the Press, Law Number 32 of 2002 concerning Broadcasting, Law Number 44 of 2008 concerning Pornography, Law Number 19 of 2016 concerning Amendments to Law No. 11/2008 concerning Information and Electronic Transactions. Law No. 33/2009 concerning Film of the 2019 Criminal Code Bill.

\section{Result and Discussion}

\subsection{Consideration Basis for Criminal Law Reform in the Pornography Countermeasures}

New crimes such as crimes based on information technology cannot be overcome by using the old legal source, namely the Criminal Code. The existence of the Criminal Code is certainly irrelevant to be used to deal with cyberporn considering the Criminal Code itself has been established since the Dutch occupation in Indonesia which at that time there was no pornography crime committed in cyberspace. To overcome this, criminal law reform is needed.

The renewal of criminal law is one of the efforts to conduct a reorientation and reformation of criminal law in accordance to the values of central social, social politic, social philosophy, and social cultural of Indonesian society which becomes the foundation of social policy, penal policy, and law enforcement policy in Indonesia. The effort to carry out the renewal of criminal law, basically is a part of the penal policy field which is inseparable with the law enforcement policy, criminal policy, and social policy. Hence, the renewal of criminal law in relation with the resolution of pornography crime basically is a part of the policy (rational effort) to renew the substance of the regulation in order to increase the effectivity of law enforcement, resolve the pornography crime to protect the people, as well as to deal with social and humanitarian issues in order to achieve the national aims of social protection and welfare. ${ }^{8}$

Aside from that, renewal of criminal law is also a part of the effort to review and evaluate the pre-existing main ideas or social philosophy, social politic, and social cultural values which had been the basis of criminal policy and criminal law enforcement policy. It would not be a renewal of criminal law if the orientation value of the criminal law has no difference with the initial one from the criminal law of the colonizer (KUHP WvS). Accordingly, the renewal of criminal law needs to be formulated with a policy-oriented approach, as well as value-oriented approach. Therefore, such renewal must be based upon the ideas of Pancasila as the fundamental value of the nation which as been the direction and core of Indonesia. The fundamental ideas of Pancasila have the balance of ideas within. Those values are as follows: ${ }^{9}$

1. Religionism

2. Humanism

3. Nasionalism

4. Democracy

\footnotetext{
${ }^{8}$ Barda Nawawi Arief, "Pembaharuan Hukum Pidana Dalam Perspektif Kajian Perbandingan (Buku II)," Cetakan Kedua, PT Citra Aditya Bakti, Bandung, 2011.

9 Dewi Bunga, "Politik Hukum Pidana Terhadap Penanggulangan Cybercrime," Jurnal Legislasi Indonesia 16, no. 1 (2019): 1-15.
} 
5. Social Justice.

Given the characteristics of the crime, the eradication of cyberporn crime is not easy. There are several things that become obstacles in overcoming this crime, inter alia: ${ }^{10}$

a. There is no common legal definition of cyberporn crime, although at the theoretical level many experts have tried to provide a definition of cyberporn crime;

b. Existing legal formulations have not been able to reach the development of crimes committed in cyberspace. Until now, Indonesia does not yet have a Law on Personal Data Protection like other countries. This temporary protection of personal data is only based on Law Number 19 of 2016 concerning Amendment to Law Number 11 of 2008 concerning Information and Electronic Transactions;

c. The characteristics of crimes in cyberspace show that these crimes can cross state jurisdictions, while the existence of international treaties regarding law enforcement against cyberporn crimes is still very limited;

d. The penal policy in dealing with cyberporn crime has not been balanced with nonpenal policies such as policies in the work environment, policies in applications, policies in schools and so on;

e. Law enforcers have to deal with billions of netizens (internet users) with various kinds of internet behavior. Inadequate law enforcement resources are a challenge in tackling cyberporn crimes;

f. Lack of evidence in case disclosure. In several cases in cyberspace, crimes occur in applications or media that are operated abroad, this will make it difficult for the police to request evidence from providers;

g. There is no clear boundary between the right to information with the right to freedom of expression in cyberspace, where both rights are human rights. The culture of the people who are less vigilant in preventing themselves from becoming victims of cyberporn crime;

h. Cyberporn crime, for example, giving a personal identity easily, uploading photos and videos that should not be shared, and trusting new people in cyberspace easily.

Pornography is considered as a violation of law in most countries and most countries have limitations related to pornography, especially those including violence or animals. ${ }^{11}$ For instance in South Korea, the Busan District Police arrested the operator of a website which offers a forum to switch sex partners. The 36 years old man was charged for propagating obscene materials and was remained in custody throughout the investigation. ${ }^{12}$

Indonesia has done cooperation with South Korea in response to the increasingly critical issue of cyber crimes in Indonesia. Cybercrime, especially cyberporn which had occurred in both Indonesia and South Korea still have an unclear timeframe of date and year in which it happened. However the occurring cyberporn in question includes harassment, impersonation, and the distribution of obscene materials which are inappropriate for the minors. Both Indonesia and South Korea have come to the

\footnotetext{
${ }^{10}$ Ibid.

11 Nur Khalimatus Sa'diyah, "FAKTOR PENGHAMBAT DALAM PENCEGAHAN DAN PENANGGULANGAN CYBERPORN DI DUNIA CYBER DALAM UPAYA PEMBAHARUAN HUKUM PIDANA," Perspektif 23, no. 2 (2018): 94-106.

12 Elin and Konstantia Novel, "Kerjasama Indonesia-Korea Selatan Dalam Mengimplementasikan Keamanan Cyber Dengan Studi Kasus Cyberporn.,” Jurnal JOM Fisip 5, no. Edisi 11 Juli, 5 (2018).
} 
realization cyberporn shall be taken seriously. With the advancement of internet in the current global era, it becomes easier for cyber criminals to commit crimes. The existence of National Cyber Body (NCB) is very much needed. In this case, if the NCB had existed, their personnel could help the police officer through the cybercrime and immigration division. The supervision and coordination of NCB is very much essential and needed by all layers of the society, as the dependency of the society, business world, as well as government towards the digital world will be increasing in the future. ${ }^{13}$

The importance of formulating penal policy in resolving cyberporn crime is correlated with the criminal law theory which acknowledges two types of crime formulation which are formal and material crimes. In formal crime, the formulation is based upon what is prohibited (including the circumstances or any conditions) by taking into account the impact of those crimes. Meanwhile for the material crimes, aside from considering the prohibited acts, also formulates the condition which was resulted from the prohibited acts in question. An action or omission can be considered as exhausting the elements of an article if it has fulfilled both of the elements, which is the conduct or omission as well as the result from such conduct or omission. From these two formulations of crimes, there are some consequences in the law enforcement itself. ${ }^{14}$ It shall further be correlated with the Conviction Theory which has developed in accordance with the changes within the society. There are three Conviction Theories, namely Absolute Theory, Relative Theory, and Integrative Theory. ${ }^{15}$

1. Absolute Theory has a view that conviction is a form of retaliation towards the crime that had happened. The orientation of this theory is towards the conduct of crime itself.

2. Relative Theory has a view that conviction is not a form of retaliation of the crime committed by the perpetrator. Instead, it is a media to serve a valuable purpose in order to protect the people and achieve properity. Hence proposing that the purpose of conviction is a form of preventive measure, which is a general prevention towards the society.

3. Integrative Theory is the mix between Absolute and Relative Theories, which imply that the conviction is given to uphold legal provisions within the society as well as to restore the humanity of the criminal. ${ }^{16}$

The enforcement of Act No. 44 of 2008 on Pornography is an effort to put into action the aforementioned penal theories. As regulated under Section II of the Pornography Act, there are prohibitions and limitation as a form of prevention towards the crime of pornography, which is in line with the Retributive Theory above. Moreover, the regulation on sanction under Section VII on Penal Regulation further goes in line with the Absolute Theory.

In several countries, soft pornography is considered not too intrusive so that it can be sold in general stores or presented on television. Conversely, hard pornography is usually strictly regulated. Pornography is considered unlawful in most countries, and in general countries have restrictions regarding pornography that involve violence or

13 Elin Konstantia Novel. Ibid. 6

${ }^{14}$ Jan and Remmelink, Hukum Pidana (Jakarta: Gramedia Pustaka Utama, 2003).

15 Djubaedah Neng, "Undang-Undang Nomor 44 Tahun 2008 Tentang Pornografi (Perspektif Negara Hukum Berdasarkan Pancasila)," Sinar Grafika, Jakarta, Hlm 3 (2011).

16 Ibid. 
animals. ${ }^{17}$ These countries actually legalize pornography. The legalization of pornography is seen as an attempt by the state to respect individual personal interests, but the prohibition of child pornography remains in countries that legalize pornography. Child pornography is categorized as a crime.

\subsection{Cyberporn Policy Formulation in Indonesia Criminal Law}

The formulation of eradication of crime in cyberspace can be seen in the regulation of these actions in the law. Provisions on the prohibition regarding pornography are specifically regulated in Law Number 44 of 2008 concerning Pornography. Article 1 number 1 of the Law states "Pornography is a picture, sketch, illustration, photo, text, sound, sound, moving picture, animation, cartoon, conversation, gestures, or other forms of messages through various forms of communication media and/or public display, which contains sexual obscenity or exploitation that violates the norms of decency in the society. "

Law Number 44 of 2008 concerning Pornography regulates the probability that the spread of pornography can be done through cyberspace. This can be seen in the definition of pornography services as referred to in Article 1 number 2 where pornographic services are all kinds of pornographic services provided by individuals or corporations through live shows, cable television, terrestrial television, radio, telephone, internet, and electronic communication and newspapers, magazines and other printed matter.

In Law Number 19 of 2016 concerning Amendments to Law Number 11 of 2008 concerning Information and Electronic Transactions, several prohibited acts are including cyberporn. These provisions are also related to the provisions in the Criminal Code. Cyberporn is regulated in Act Number 19 of 2016 concerning Amendment to Act Number 11 of 2008 concerning Electronic Information and Transactions, namely acts that violate decency:

a. In article 27 paragraph (1) of Law Number 11 of 2008 which is in force after being amended to Act Number 19 of 2016 concerning Amendment to Act Number 11 of 2008 concerning Information and Electronic Transactions states: "Everyone intentionally and without the right to distribute and/or transmit and/or make it accessible Electronic Information and/or Electronic Documents that have content that violates decency. "

b. Law Number 11 of 2008 concerning Information and Electronic Transactions itself does not explain the act of distributing andor transmitting and/or making accessible Electronic Information and/or Electronic Documents having contents that violate decency. Acts that violate decency through the internet media itself refers to the Criminal Code. The moral offenses are regulated in Chapter XIV of Book II of the Criminal Code. The actions classified as moral offenses are as follows:

1) Crime of deliberately violate decency (Article 281 of Criminal Code)

\footnotetext{
${ }^{17}$ Sa'diyah, "FAKTOR PENGHAMBAT DALAM PENCEGAHAN DAN PENANGGULANGAN CYBERPORN DI DUNIA CYBER DALAM UPAYA PEMBAHARUAN HUKUM PIDANA.”
} 
2) Pornography (Article 282, 283, 283 bis of Criminal Code)

3) Adultery (Article 284 of Criminal Code)

4) Rape (Article 285 of Criminal Code)

5) Having sex with a woman who is not his wife in a faint or helpless state (Article 286 of Criminal Code)

6) Having sex with a minor (Article 287 of Criminal Code)

7) Having sex with a wife who is not yet to be married (Article 288 of Criminal Code)

8) Molestation (Article 289 of Criminal Code)

9) Molestation to a person who is in faint of helpless state (Article 290(1) of Criminal Code)

10) Molestation (Article 290 of Criminal Code).

Judging from the substance, cyberporn is included in the formulation of moral offense in the Criminal Code because pornographic offenses in the Criminal Code include as follows:

1) Article 282 regulates: a) publicly broadcasting, displaying or attaching, written writings, drawings or objects that violate decency b) makes the writing, picture or object (with the intention to broadcast be displayed or posted in public) c) bring it in to the country, forward it, bring it out from the country, or have it in stock (with the intention of being broadcast, exhibited or posted in public) or d) offering it or showing it as something accessible (without elements in public);

2) Article 283 regulates: offering, giving, submitting or displaying writings, pictures or objects that violate decency to someone underage, and knows or deserves to be suspected that he is not yet seventeen years old;

3) Article 533 regulates: a) in public traffic, displaying or sticking pictures or objects, which arouse/stimulate teenage lust $b$ ) offering or referring how to get writings, pictures or items that can stimulate teenage lust (without elements in public places) c) offering, giving, submitting or displaying such pictures or objects (which can arouse lust), to someone underage or under 17 (without elements in public places).

If we see the above provisions of the Criminal Code, some weaknesses are related to the Indonesian territory, the provisions of the Criminal Code above can only be applied if the offense is carried out within the territory of Indonesia. The offense committed by foreigners outside the Indonesian territory cannot be reached by the Criminal Code. Furthermore, in addition to the Criminal Code, cyberporn can also be criminalized by Law Number 32 of 2002 concerning Broadcasting because this Act contains provisions as follows:

1) Article 57 jo 36 (5) criminalize broadcast which (among others) accentuate obscene elements;

2) Article 57 jo 36 (6) criminalize broadcasts that mock, disparage, harass and/or ignore religious values, the dignity of Indonesian people; 
3) Article 58 jo 46 (3) criminalizes commercial advertisements broadcast which contain (among other things): a) matters that are contrary to the decency of society and religious values; and/or b) exploitation of children under the age of 18 .

The provisions of the Criminal Code and the Law Number 32 of 2002 concerning Broadcasting share the same weaknesses with regard to territorial jurisdiction. Besides that, there are several other weaknesses: there is no determination of the offense qualification (as a crime or violation), and there is no provision regarding corporate criminal liability, even though the broadcasting and advertising offenses are closely related to the corporation. According to articles 14 and 16 of Law Number 32 of 2002 regarding Broadcasting, broadcasting institutions are in the form of legal entities.

Seeing from the lack of territorial regulation cconcerning locus delicti of the act of cyberporn, some formulations towards the criminal law are needed to form a renewal towards the criminal law, namely:

i. Bilateral cooperation with some states which already has the same legal system as Indonesia, aside from the one concluded with South Korea, in order to prevent the jurisdiction issue in resolving cyberporn.

ii. Conduct a recodification regarding the locus delicti provisions of cyberporn in the Criminal Code (KUHP) and in other legislations whether it is directly or indirectly related to cyberporn;

iii. Resolve the cyberporn in a philosophical, sociological, political, and diplomatic approaches when the crime is conducted beyond the territory of Indonesia;

iv. With the presence of penal legal politics, it is hoped that the renewal of criminal law carried out by the state through some respective bodies can create a regulation which further becomes a legislation where it must be fully expressing the national aims, culture, and characteristic of the nations. Further, it shall be done to the substance of the law, structure of the law, as well as the renewal of the criminal law itself.

v. Penal policy can be operated through some steps, which are formulating step (legislative policy), application step (judicial and jurisdiciary policies), as well as execution (executory and administrative policies). From those steps, the formulation of regulation is the most strategi one as a preventive measure of crimes conducted through penal policy. The setback of legislative policy is a strategical mistake which can bar the prevention and resolution effort of the crime in the application and execution steps.

In the development of modern criminal law, crime prevention is not only done through a penal policy but also a non-penal policy. Even non-penal policies must be prioritized given the problem of cyberporn is not only related to legal issues but also problems of people's behavior. Cyber pornography activities are not only contrary to the norms of decency, religion, politeness, law that clearly will harm and damage the moral order of society. ${ }^{18}$

Christianto, in his research entitled "Measuring cyber pornography based on Indonesian living law: A study of current law finding method" states that "Law enforcement is very rigid and formal, regardless of the values of law which exist in the

\footnotetext{
${ }^{18}$ Mahsun Ismail, “Kebijakan Hukum Pidana Cyberpornography Terhadap Perlindungan Korban,” Jurnal Hukum Ekonomi Syariah 1, no. 2 (2019): 117-34.
} 
society, especially for pornography." 19 Rigid law enforcement is caused by law enforcement bound to formal rules without looking at other aspects of the non-penal policy. Legal supports are needed to complement cyberporn prevention policy, this can be for instance, the arrangement of the public awareness on the concept of legal culture change that involves forms of variation of life as theoretical base cyberporn crime prevention. Cyberporn principally refutes the norms and culture of the people. Thus, strengthening moral and legal culture of society is the key to overcome cyberporn. ${ }^{20}$

\section{Conclusion}

Judging from its substance, cyberporn is included in the formulation of moral offenses in the Criminal Code because of pornographic offenses in the Criminal Code such as Article 282, Article 283, and Article 533. However, the provisions in the Article have weaknesses, namely related to the territorial territory of Indonesia, the provisions of the Criminal Code above can only be applied to offenses conducted in the territory of Indonesia. The offense committed by foreigners outside the Indonesian territory is outside the scope of the Criminal Code. Furthermore, in addition to the Criminal Code, cyberporn can also be criminalized by using Law Number 32 of 2002 concerning Broadcasting because this Law there are provisions of Article 57 jo 36 (5), Article 57 jo.36 (6), and Article 58 jo 46 (3). However, the provisions in the Criminal Code and Law Number 32 of 2002 concerning Broadcasting share the same weaknesses, that is territorial jurisdiction. Besides that, there are other weaknesses: there is no determination of offense qualifications (as a crime or violation), and there are no provisions regarding corporate criminal liability, even though the broadcasting and advertising offenses are closely related to the corporation. The formulation of the 2019 Criminal Code Bill, specifically regulating cyberporn crime, is more emphasized on the scope and sanctions. In tackling cyberporn, the government needs to do bilateral cooperation with several countries, so that cyberporn criminal acts do not clash with territorial jurisdiction.

\section{Acknowledgments}

Our gratitude goes to the Universitas Pendidikan Nasional and the Faculty of Law and Social Sciences, Universitas Pendidikan Nasional for providing platforms, opportunities and encouragement in every study conducted by lecturers.

\section{References}

Angkupi, Prima. "Cultural Approaches in Cyberporn Crime Prevention." Jurnal Dinamika Hukum 17, no. 2 (2017): 225-31.

Arief, Barda Nawawi. "Pembaharuan Hukum Pidana Dalam Perspektif Kajian Perbandingan (Buku II)." Cetakan Kedua, PT Citra Aditya Bakti, Bandung, 2011.

Bossler, Adam M, and Tamar Berenblum. "Introduction: New Directions in Cybercrime Research." Taylor \& Francis, 2019.

\footnotetext{
${ }^{19}$ Hwian Christianto, "Measuring Cyber Pornography Based on Indonesian Living Law: A Study of Current Law Finding Method," International Journal of Law, Crime and Justice 60 (2020): 100348.

${ }^{20}$ Prima Angkupi, "Cultural Approaches in Cyberporn Crime Prevention," Jurnal Dinamika Hukum 17, no. 2 (2017): $225-31$.
} 
Bunga, Dewi. "Politik Hukum Pidana Terhadap Penanggulangan Cybercrime." Jurnal Legislasi Indonesia 16, no. 1 (2019): 1-15.

Choi, Jaeyong, and Ilhong Yun. "Do Moral Beliefs Condition the Impact of Low SelfControl on Digital Piracy?" Deviant Behavior, 2019, 1-13.

Christianto, Hwian. "Measuring Cyber Pornography Based on Indonesian Living Law: A Study of Current Law Finding Method." International Journal of Law, Crime and Justice 60 (2020): 100348.

Dwi, and Haryadi. "Kebijakan Formulasi Hukum Pidana Terhadap Penanggulangan Cyberporn Dalam Rangka Pembaharuan Hukum Pidana Di Indonesia." In Pembaharuan Hukum Pidana Di Indonesia, Program Magister Ilmu Hukum Universitas Diponegoro, 2007.

Elin, and Konstantia Novel. "Kerjasama Indonesia-Korea Selatan Dalam Mengimplementasikan Keamanan Cyber Dengan Studi Kasus Cyberporn." Jurnal JOM Fisip 5, no. Edisi 11 Juli, 5 (2018).

Ismail, Mahsun. "Kebijakan Hukum Pidana Cyberpornography Terhadap Perlindungan Korban." Jurnal Hukum Ekonomi Syariah 1, no. 2 (2019): 117-34.

Jamaldi, J L, and Ferdi Ferdi. "TEKNIK DAN TAKTIK PENYIDIK DALAM PENETAPAN TERSANGKA PADA TINDAK PIDANA PORNOGRAFI MELALUI INTERNET (Studi Pada Direktorat Reserse Kriminal Khusus Polda Sumbar)." UNES Law Review 1, no. 3 (2019): 282-90.

Jan, and Remmelink. Hukum Pidana. Jakarta: Gramedia Pustaka Utama, 2003.

Neng, Djubaedah. “Undang-Undang Nomor 44 Tahun 2008 Tentang Pornografi (Perspektif Negara Hukum Berdasarkan Pancasila)." Sinar Grafika, Jakarta, Hlm 3 (2011).

Puspasari, Ratih Mega. "Reconstruction of Criminal Sanctions On Actors Of Online Prostitution Based On Justice Value." Law Development Journal 1, no. 1 (2019): 3238.

Puspitosari, Hervina, and Ashinta Sekar Bidari. "ETHIC CYBER STRENGTHENING ASCRIMINAL LAW POLICY FORMULATIONS IN RESPONSE CYBERPORN." UNTAG Law Review 1, no. 2 (2017): 30-37.

Rosalind, and A Fanggi. "Kebijakan Hukum Pidana Dalam Upaya Penanggulangan Cyberporn." Jurnal Hukum Yurisprudeensia 17, no. 7 (2019).

Sa' diyah, Nur Khalimatus. "FAKTOR PENGHAMBAT DALAM PENCEGAHAN DAN PENANGGULANGAN CYBERPORN DI DUNIA CYBER DALAM UPAYA PEMBAHARUAN HUKUM PIDANA." Perspektif 23, no. 2 (2018): 94-106.

\section{Website}

Ariani, Desi. (2015). Kebijakan Hukum Pidana (Penal Policy) Dalam Penanggulangan Cyber Crime di Bidang Kesusilaan, diakses pada ; https://www.kompasiana.com/desiariani/5500677ca333115b73510bee/kebija kan-hukum-pidana-penal-policy-dalam-penggulangan-cyber-crime-dibidang-kesusilaan, diakses tanggal 8 Januari 2020 